\title{
Organic anions and potassium salts in nutrition and metabolism
}

\author{
Christian Demigné*, Houda Sabboh, Caroline Puel, Christian Rémésy and Véronique Coxam \\ Unité Maladies Métaboliques et Micronutriments, INRA de Clermont-Ferrand-Theix, CRNH d'Auvergne, \\ 63122 St-Genès-Champanelle, France
}

\begin{abstract}
The present review examines the importance of dietary organic anions in preventive nutrition. Organic anions are chiefly supplied by plant foods, as partially neutralised K salts such as potassium citrate, potassium malate and, to a lesser extent, oxalate or tartrate salts. Animal products may also supply $\mathrm{K}$ anions, essentially as phosphate, but also as lactate as a result of fermentative or maturation processes, but these $\mathrm{K}$ salts have little alkalinising significance. Citrate and malate anions are absorbed in the upper digestive tract, while a substantial proportion is probably metabolised in the splanchnic area. Whatever their site of metabolism, these anions finally yield $\mathrm{KHCO}_{3}$ which is used by the kidneys to neutralise fixed acidity. This acidity essentially reflects the oxidation of excess $\mathrm{S}$ amino acids to sulfate ions, which is mainly related to the dietary protein level. Failure to neutralise acidity leads to low-grade metabolic acidosis, with possible long-term deleterious effects on bone $\mathrm{Ca}$ status and on protein status. Furthermore, low-grade acidosis is liable to affect other metabolic processes, such as peroxidation of biological structures. These metabolic disturbances could be connected with the relatively high incidence of osteoporosis and muscle-protein wasting problems observed in ageing individuals in Europe and Northern America. Providing a sufficient supply of K organic anions through fruit and vegetable intake should be recommended, fostering the actual motivational campaigns ('five (or ten) per d') already launched to promote the intake of plant foods rich in complex carbohydrates and various micronutrients.
\end{abstract}

Organic anions: Potassium: Calcium: Metabolic acidosis: Osteoporosis

\section{Introduction}

Compared with the Stone Age diet, the modern human diet is excessive in salt and deficient in fruit and vegetables, which are rich in $\mathrm{K}^{+}$and organic anions such as citrate. The mismatch between the modern diet's makeup of these electrolytes and the still ancient renal capacity to process them gives rise to $\mathrm{NaCl}$ overload, low-grade $\mathrm{K}^{+}$deficiency and low-grade metabolic acidosis (Frassetto et al. 2001). The $\mathrm{pH}$ threshold under which food acidity is perceived as aggressive is relatively low, in the range of 3-4. In fact, this acid perception is conditional because it may be modulated by other constituents of the food, such as cations or simple sugars. This acceptance of acidic foods is probably an inherited feature and might reflect the fact that acidic foods are generally better preserved, from a nutritional as well as from a safety point of view, compared with foods showing neutral or even slightly alkaline characteristics. In most cases, a food's acidity reflects the presence of organic anions, such as malate, citrate or lactate, together with inorganic anions (for example, phosphate).

Organic anions are absorbed mainly in the digestive tract and metabolised in various tissues, especially those of the splanchnic area (intestine, liver), and finally yield $\mathrm{CO}_{2}$ and energy. Since they are present in partly neutralised forms, mainly as $\mathrm{K}$ salts, they may be considered as virtual precursors of $\mathrm{KHCO}_{3}$, an important alkalinising chemical species especially for kidney function.

In the present review we will document the various sources of organic anions liable to be absorbed with plant foods and therefore available in the digestive tract lumen, as well as the different possibilities of in situ generation of some anions from other diet constituents (especially carbohydrates). The metabolic impact of these various anions will be examined, particularly as regards the control of the acid-base equilibrium in the body, and the various physiopathological consequences that might arise from disturbances of this equilibrium.

\section{Origin of the organic anions absorbed from the digestive tract}

\section{Anions from plant foods}

Anions. Except for ripened cereals, intrinsically poor in organic anions, and to a certain extent legumes, most plant 
foods contain substantial quantities of organic anions; from $100 \mathrm{mg} / 100 \mathrm{~g}$ fresh weight (fw) up to $4000 \mathrm{mg} / 100 \mathrm{~g} \mathrm{fw}$, for the richest sources such as citrus fruits. In terms of molar concentrations, these values represent 0.5 to $20 \mathrm{mmol}$ citrate units/100 g fw (Fig. 1). Malate and citrate are polycarboxylic anions which, at the acidic $\mathrm{pH}$ prevailing in plant products, are partially neutralised by cations (for example, malic acid in apples is virtually in a potassium malate ${ }^{1-}$ form). These organic anions are frequently intermediate metabolites of the tricarboxylic cycle but, in some foods, the prevalent anion is not metabolisable, for example oxalate (red beet, spinach, rhubarb) or tartrate (grapes). Besides, relatively low concentrations of additional organic anions may be found, such as fumate or succinate, as well as various phenolic acids (quinate, ferrulate, caffeate, chlorogenate). Malate and citrate anions are frequently present simultaneously in a large variety of plant foods, but malate is the predominant anion in some fruits and vegetables (apples, cherries, plums, aubergines, cucumbers) whereas citrate is the major anion of citrus fruits, kiwi and members of the Solanaceae family (potatoes, tomatoes).
Some anions, generally present in small amounts, probably exert pharmacological effects; for example, glucarate is found in plant foods such as cabbages, tomatoes, grapefruits and apples. Glucarate is a precursor of D-glucuro-1,4lactone, an inhibitor of $\beta$-glucuronidases, which could affect the detoxification of carcinogens and other promoters of carcinogenesis through a decreased hydrolysis of their glucuronides (Walaszek et al. 1997). Cholesterol-lowering properties have also been ascribed to D-glucuro-1,4-lactone (Yoshimi et al. 2000). Hydroxycitrate, present in some FarEastern fruits such as Garcinia, is known as an inhibitor of lipogenesis and has also been examined as a possible anorexigen; however, the trials were not conclusive (Heymsfield et al. 1998).

Accompanying cations. The $\mathrm{K}$ content of fruits is generally between 2.5 and $10 \mathrm{mEq} / 100 \mathrm{~g} \mathrm{fw}$ and that of vegetables is usually higher, sometimes exceeding $15 \mathrm{mEq} / 100 \mathrm{~g}$ fw. In fact, the most salient feature which distinguishes fruits and vegetables is the $\mathrm{K}$ :organic acids concentration ratio (in $\mathrm{mEq}$ ); this ratio is basically lower than 0.5 in most

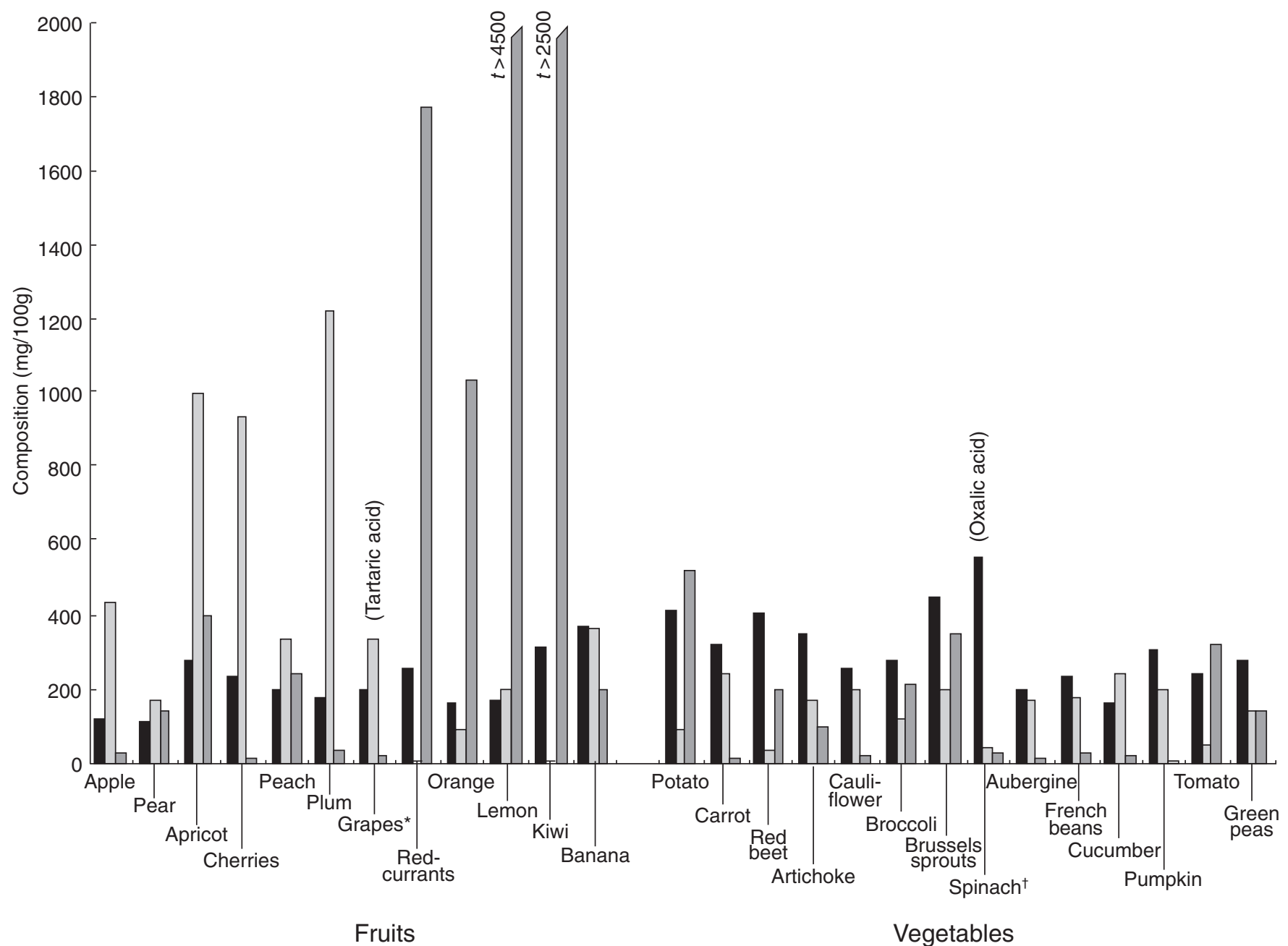

Fig 1. $\mathrm{K}(\square)$, malic acid $(\square)$ and citric acid $(\square)$ composition of some examples of usual plant foods (mg/100 g fresh weight). ${ }^{*}$ Tartaric acid content is shown for grapes instead of malic acid content. $†$ Oxalic acid content is shown for spinach instead of $\mathrm{K}$ content. 
fruits whilst it always exceeds 1 (up to 2.6 in pumpkins) in vegetables. In other terms, organic acidity of vegetables (frequently lower than in fruits) is more completely neutralised by $\mathrm{K}$ ions and vegetables exhibit a greater alkalinising potency. It must be noted that, within the fruit and vegetable groups, some foods show an atypical composition, which has some nutritional and culinary background. A fruit such as banana exhibits a K:organic acids concentration ratio $>1$ (coherent with the possibility of using bananas as a vegetable) and this ratio is much lower than that of most of the other vegetables except for tomato, probably reflecting its possible utilisation as fruit (for example, for juice confectionery).

The daily food supply of organic anions is obviously dependent on fruit and vegetable intake. It could be in the range of 1-2 g/d in low-plant-food consumers, and easily reaches $3-4 \mathrm{~g} / \mathrm{d}$ in subjects consuming a diversified omnivorous diet and more than $5 \mathrm{~g} / \mathrm{d}$ in vegetarian individuals. These values of intake are close to those for $\mathrm{K}$, which is consistent with the fact that organic anions are mainly $\mathrm{K}$ salts, but it must be kept in mind that $\mathrm{K}$ is also present in food products of animal origin.

Influence of cultivar, maturity or food processing. The degree of maturity influences the concentrations of organic acids in plant foods, for example citric acid in citrus fruits accumulates during fruit development but tends to decline at the stage of maturity. Food processing such as boiling is probably a cause of organic salt losses, especially for vegetables since fruits are generally consumed uncooked. This point is still incompletely documented, but there is little doubt that foods that are steamed or briefly fried probably maintain greater concentrations of potassium malate or citrate than if cooked using procedures that lead to extensive leaching (Table 1).

\section{Anions in animal foods}

These foods are frequently poor in organic anions if consumed directly but, most frequently, they contain substantial quantities of organic anions resulting from maturation and/or fermentation processes. An exception is cows' milk, which contains noticeable amounts of citrate $(5-8 \mathrm{mmol} / \mathrm{l})$. On the other hand, fermented dairy products are rich in lactate anions, arising from lactose fermentation (by Lactobacilli and Streptococci). Yoghurts contain more than $100 \mathrm{mmol}$ lactic acid/l; thus a standard serving of $125 \mathrm{~g}$ yoghurt supplies about $1.3 \mathrm{~g}$ lactic acid. Cheeses are also enriched in lactate, but its concentration may be very different according to the type of cheese.

Table 1. Influence of the cooking process on the potassium level in potatoes

\begin{tabular}{lc}
\hline Treatment & Concentration $(\mathrm{mg} / 100 \mathrm{~g}$ food $)$ \\
\hline Uncooked & 530 \\
Boiled & 330 \\
Oven cooked & 540 \\
French fries & 700 \\
Chips & 1190 \\
\hline
\end{tabular}

The L-lactate anion is part of the anionic profile of muscles in vivo (contributing $5-10 \mathrm{mmol} / \mathrm{kg}$ fw, which is marginal). However, it accumulates in muscle tissues during the process of meat maturation through anaerobic glycolysis from glycogen stores and it can be present in substantial concentrations (50 to $80 \mathrm{mmol} / \mathrm{kg}$ ).

It appears, therefore, that animal foods may represent a non-negligible source of organic anions, but in a markedly distinct pattern from that observed in plant foods. The organic anion present in animal products is typically lactate and this anion is produced secondarily (through postmortem metabolism or fermentation) in matrixes where the unmetabolisable anions, chiefly phosphate, prevail. Therefore, the alkalinising potential of animal foods is quite limited even when foods contain noticeable $\mathrm{K}$ concentrations (Oh, 2000). The quantities of organic anions ingested with animal foods may be estimated at about $1 \cdot 5-2 \cdot 0 \mathrm{~g} / \mathrm{d}$ and it seems probable that, in subjects consuming a high-meat and -dairy products diet, this supply will be greater than that from plant foods whereas it will be marginal in vegetarian individuals (Fig. 2).

\section{Anions produced in situ in the digestive tract}

There is a permanent generation of substantial quantities of organic anions in the large intestine, essentially SCFA (namely acetate, propionate and butyrate). SCFA are the endproducts of microbial symbiotic fermentation present in the distal part of the digestive tract, which uses as substrates dietarily unavailable carbohydrates (fibre, resistant starch) and endogenous sources (sloughed epithelial cells, digestive secretions). Besides SCFA, other organic anions (succinate, lactate, galacturonate) can be found in notice-

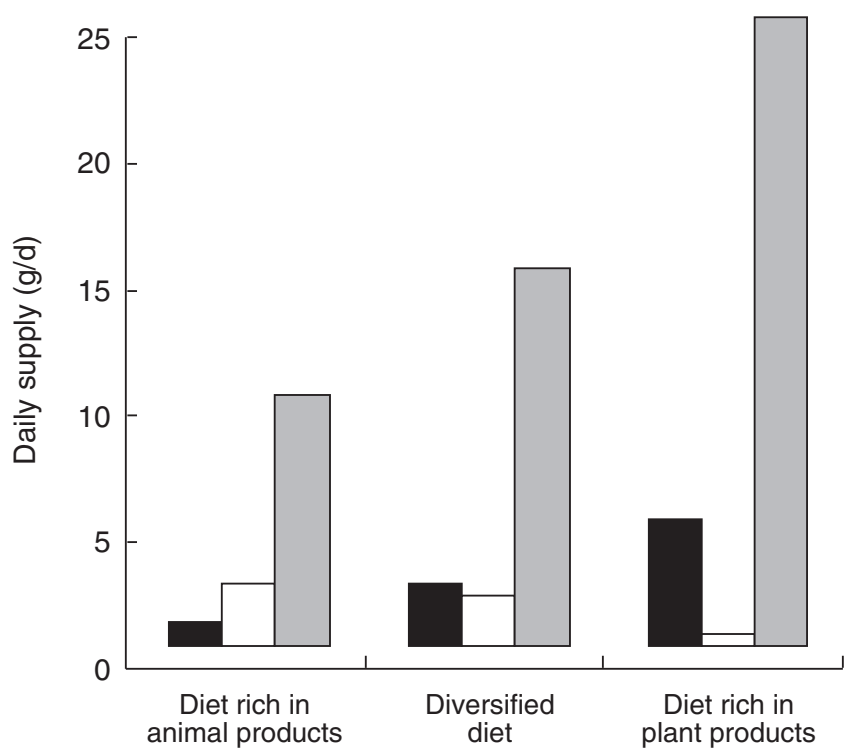

Fig 2. Estimation of the daily availability of organic anions from plant foods (chiefly malate and citrate; $\boldsymbol{\square}$ ), from animal products (chiefly lactate; $\square$ ) and from large-intestine fermentation (chiefly SCFA, i.e. acetate, propionate and butyrate; $\square$ ) with various diet patterns. 
able amounts, under specific conditions (acidic fermentation, pectin hydrolysis) (Demigné et al. 1999; Aprikian et al. 2003). The daily intake of fibre in Western countries is in the range of 15-20 g/d; thus, together with endogenous sources, a total substrate supply of $30 \mathrm{~g} / \mathrm{d}$ for colonic fermentation is considered as probable. The overall yield of the colonic fermentation for SCFA production is roughly $50 \%$, which implies that this process generates around $15 \mathrm{~g}$ SCFA/d which are efficiently absorbed (>90\%) through the colonic mucosa (Cummings \& Macfarlane, 1997). It appears therefore that the production of organic anions in the colon, which is closely dependent on nutritional conditions, is a major source of organic anions absorbed from the digestive tract.

The committed processes for SCFA absorption in the large intestine are complex and diversified (Sellin, 1999); some of them encompass a concomitant absorption of cations $\left(\mathrm{K}^{+}\right.$and/or $\left.\mathrm{Na}^{+}\right)$and might therefore afford alkalinising opportunities (Kunzelmann \& Mall, 2002). However, the overall impact of colonic fermentation on the acid-base equilibrium is still poorly understood since, for example, some processes involved in SCFA absorption require an anionic exchange between an $\mathrm{SCFA}^{-}$and an $\mathrm{HCO}_{3}{ }^{-}$, transferred from the extracellular body fluids into the colonic lumen (Demigné et al. 1999). Butyrate is a major energetic fuel for the colonic mucosa and has been shown to be metabolised in priority compared with other substrates such as glucose or glutamine (Mortensen \& Clausen, 1996). The glutamine-sparing effect could be relevant in terms of acid-base control since glutamine is an effective precursor of neutralising metabolites $\left(\mathrm{HCO}_{3}{ }^{-}\right.$and $\mathrm{NH}_{3}$ ) in the kidneys (Welbourne \& Joshi, 1990). The colon-liver enterohepatic cycling of $\mathrm{NH}_{3}-\mathrm{N}$ is also a process with an equivocal significance. This is because urea transfer in the large intestine lumen generates two $\mathrm{NH}_{3}$, which can act as a sink for $\mathrm{H}^{+}$through $\mathrm{NH}_{4}^{+}$formation, but a part of colonic $\mathrm{NH}_{3}$ is also reabsorbed and further detoxified to urea in the liver, a purported $\mathrm{HCO}_{3}{ }^{-}$-consuming process (Häussinger, 1997).

These considerations indicate that the actual influence of intestinal fermentation on the acid-base equilibrium is difficult to evaluate. Furthermore, such an influence (if any) is probably quite different when colonic fermentation is poorly active, in practically neutral $\mathrm{pH}$ conditions, compared with when substrate availability allows the development of acidic fermentation (De Groot et al. 1995), establishing an $\mathrm{H}^{+}$concentration gradient between the bulk colonic medium and extracellular fluid ranging from 10 to 50 .

\section{Absorption and metabolism}

\section{Absorption}

Most of the organic anions from foods are effectively absorbed in the small intestine, or even in the stomach by diffusion if the protonated form is lipophilic (for example, acetate or butyrate). Citrate and other intermediates of the tricarboxylic cycle (succinate, $\alpha$-ketoglutarate and probably malate) are transferred into the enterocytes through a secondary active transport requiring $\mathrm{Na}^{+}$movements across the plasma membrane (Na-dependent dicarboxylate transporter). Various transporters of this type have been identified in the digestive tract, including the colon; these transporters differ in their $\mathrm{K}_{\mathrm{m}}$ for substrates, from about $1 \mathrm{mmol} / \mathrm{l}$ to about only $10 \mu \mathrm{mol} / \mathrm{l}$ (Pajor, 1999). The coupling of di- or tricarboxylate anions with that of $\mathrm{Na}^{+}$has been used in oral rehydrating formulations designed for the treatment of diarrhoea. Other dietary anions such as lactate are also readily absorbed, through a relatively specific process, since absorption of the L-isomer is markedly faster than that of its D-counterpart.

The other organic anions (oxalate, tartrate, phenolic acids) in the diet are generally less absorbable than malate, citrate or lactate, they are poorly metabolised in the body's tissues and the absorbed fraction is essentially channelled towards excretion by the kidneys.

Oxalic acid is abundant in a limited group of plant foods (red beet, spinach and rhubarb). Its absorption exhibits some particularities. Oxalate absorption is: (i) dependent on the dietary $\mathrm{Ca}$ availability; (ii) favoured in the colon by acidic fermentation conditions, together with possibilities of complete breakdown by the host microflora; (iii) possibly balanced by an opposite secretion of oxalate into the intestinal lumen (Hatch \& Freel, 1995; Albihn \& Savage, 2001). Hautmann (1993) has also reported that the stomach could be a critical site for intestinal oxalate absorption.

Tartrate is essentially found, in its natural L(+) form, in grapes. This anion is partly absorbed from the digestive tract; it has been shown that colonic bacteria metabolise the bulk of ingested tartrate in human subjects, and only $14 \%$ of ingested tartrate appears unchanged in the urine (Chadwick et al. 1978).

The other organic anions present in lesser amounts in plant foods (quinate, ferrulate, caffeate, chlorogenate) are part of the phenolic acids group. Phenolic acids may be absorbed at different levels of the digestive tract (small intestine, colon) and are then excreted by the kidneys in various conjugated forms.

\section{Metabolism}

The intestine itself is a site of metabolism for malate and citrate (Wolffram et al. 1994), yielding $\mathrm{CO}_{2}$ or other intermediate metabolites such as amino acids (alanine, proline, etc) or lactate. This domain is, in fact, still incompletely known and certainly merits further investigation.

The liver is a major site for organic anions metabolism and the removal of circulating dicarboxylates involves at least two transport systems; an $\mathrm{Na}^{+}$-dicarboxylate cotransport and a system of anion exchange (Moseley et al. 1992; Zimmerli et al. 1992). The transferred anions are then channelled into various metabolic pathways, either towards complete oxidation, incorporation into glucose and liver glycogen or use for glutamine synthesis in perivenous hepatocytes (Stoll et al. 1991). This last point is noteworthy because it suggests that organic anions might exert an alkalinising effect not only through $\mathrm{HCO}_{3}^{-}$generation, but also through glutamine production (by being used in the kidneys for $\mathrm{HCO}_{3}^{-}$and $\mathrm{NH}_{4}^{+}$formation). In fact, there are arguments supporting the view that a sub-population of liver cells $(5-7 \%)$ is particularly adapted for coupling organic 
anions and glutamine metabolism, through the predominance or exclusive presence of various processes. These processes involve: glutamine synthase; Na-dependent glutamate transport; enriched plasma membrane SN1 (amino acid transporter); malate (and closely related anions) membrane transport; less acidic cytoplasm (Häussinger et al. 1989).

In fact, whatever the pathway for the metabolism of organic anions, their $\mathrm{C}$ is finally oxidised to $\mathrm{CO}_{2}$ (in equilibrium with circulating $\mathrm{HCO}_{3}^{-}$in extracellular fluids) in the shorter or longer term. Insofar as these anions are present in foods as $\mathrm{K}^{+}$salts, which are highly digestible, it can be assumed that the endproduct of their metabolism is $\mathrm{KCO}_{3}^{-}$.

\section{Nutrition and acid-base equilibrium}

\section{Acidifying characteristics of different types of foods}

During their complete oxidation, carbohydrates or lipids do not generate unmetabolisable acidity, even if their partial oxidation (into lactic acid or ketone bodies, respectively) may result in metabolic acidosis when excessive. In contrast, proteins contain various amino acids whose catabolism is liable to affect the acid-base equilibrium. The impact of the oxidation of proteins on this equilibrium is not unequivocal. Basic amino acids ('cationic', such as lysine, histidine or arginine) yield various metabolites together with $\mathrm{H}^{+}$, and $\mathrm{S}$ amino acids (methionine, cysteine) are also acidogenic because they yield sulfate anions (unmetabolisable acidity). However, oxidation of the dicarboxylic amino acids ('anionic', such as glutamate or aspartate) 'consumes' acidity. Even if some proteins (for example, rich in neutral and anionic amino acids) could theoretically be alkalinising, the fact remains that most of the dietary proteins (especially those well balanced for their amino acid composition) are acidifying (Remer \& Manz, 1995).

\section{Evaluation of the acidifying potential of various foods}

Basically, a food or a diet which provides an excess of inorganic anions (fixed anions) such as $\mathrm{Cl}^{-}, \mathrm{H}_{\mathrm{n}} \mathrm{PO}_{4}^{(3-\mathrm{n})-}$ or $\mathrm{SO}_{4}{ }^{2-}$, compared with inorganic cations $\left(\mathrm{Na}^{+}, \mathrm{K}^{+}, \mathrm{Ca}^{2+}\right.$, $\mathrm{Mg}^{2+}$ ) will be ascribed acidifying properties, in keeping with the classical 'dietary ash hypothesis'. The net excretion of acidity by kidneys is referred to as:

$$
\left(\mathrm{Cl}+\mathrm{P}+\mathrm{SO}_{4}+\text { organic anions }\right)-(\mathrm{Na}+\mathrm{K}+\mathrm{Ca}+\mathrm{Mg}) .
$$

The urinary excretion of $\mathrm{SO}_{4}$ and all the other ions may be estimated from the data of food intake and food composition tables, using specific absorption coefficients, which are, for example: proteins, $75 \% ; \mathrm{P}, 63 \% ; \mathrm{Cl}, 95 \%$; $\mathrm{Na}$, $95 \% ; \mathrm{K}, 80 \%$; $\mathrm{Ca}, 25 \% ; \mathrm{Mg}, 23 \%$. In addition, the valences (2 for $\mathrm{Ca}$ and $\mathrm{Mg}$ ) and the ionic charge of $\mathrm{PO}_{4}$ at physiological $\mathrm{pH}(1 \cdot 8)$ are also taken into account as well as, for proteins, an average percentage of methionine $(2.4 \%)$ and cysteine $(2.0 \%)$ (Remer, 2000). Practically, the above calculation may be simplified by considering that $\mathrm{Na}$ and $\mathrm{Cl}$ are essentially provided as $\mathrm{NaCl}$ in most foods.

According to these assumptions, it is possible to estimate a potential renal acid load (PRAL) for various foods, which ranges between $34 \mathrm{mEq} / 100 \mathrm{~g}$ (Parmesan) and -21 $\mathrm{mEq} / 100 \mathrm{~g}$ (grapes). As a general rule, fruits and vegetables display negative PRAL values, milk and yoghurt are close to 0 and meat, fish, poultry and cheese (and some cereal products) exhibit positive PRAL values (Remer, 2000) (Fig. 3). At the scale of a complex diet fed during several days, renal acidity excretion may change from about 10 $\mathrm{mEq} / \mathrm{d}$ up to $60-70 \mathrm{mEq} / \mathrm{d}$ during the transition from a lacto-ovo-vegetarian diet to an omnivorous diet moderately rich in proteins. Only minute differences are to be found between the measured values and values obtained through the calculation of the PRAL of consumed foods. In parallel the urinary $\mathrm{pH}(6.7$ in initial conditions) may drop down to 5.9 (Remer \& Manz, 1995). These urinary balances also depend on the rate of organic anions excretion (especially citrate), which is relatively constant for each individual.

Excessive dietary proteins from food with high PRAL adversely affect bone (each additional $1 \mathrm{~g}$ dietary protein results in an additional loss of about $1.75 \mathrm{mg} \mathrm{Ca} / \mathrm{d}$ ), unless buffered by the consumption of alkali-rich foods or supplements (Barzel \& Massey, 1998; Heaney, 2001). Abelow et al. (1992) reported that the incidence of hip fractures in women aged 50 years and older correlates positively with a country's average annual per capita consumption of animal protein. Data from Frassetto et al. (2000) and Sellmeyer et al. (2001) strongly strengthen the generalisation of a worldwide association of hip fractures in women with animal protein consumption. In fact, the decisive risk factor for hip fracture would not be the rate of production of fixed acid from animal protein but the net rate of endogenous acid production, when all sources of dietary acid and base are considered. Thus, a vegan diet with protein derived equally from grains and legumes would deliver at least as many $\mathrm{mmol} \mathrm{S/g}$ protein as would a meat-based diet (Heaney, 2001), but it yields significantly lower rates of net endogenous acid production than do mixed animal and vegetable

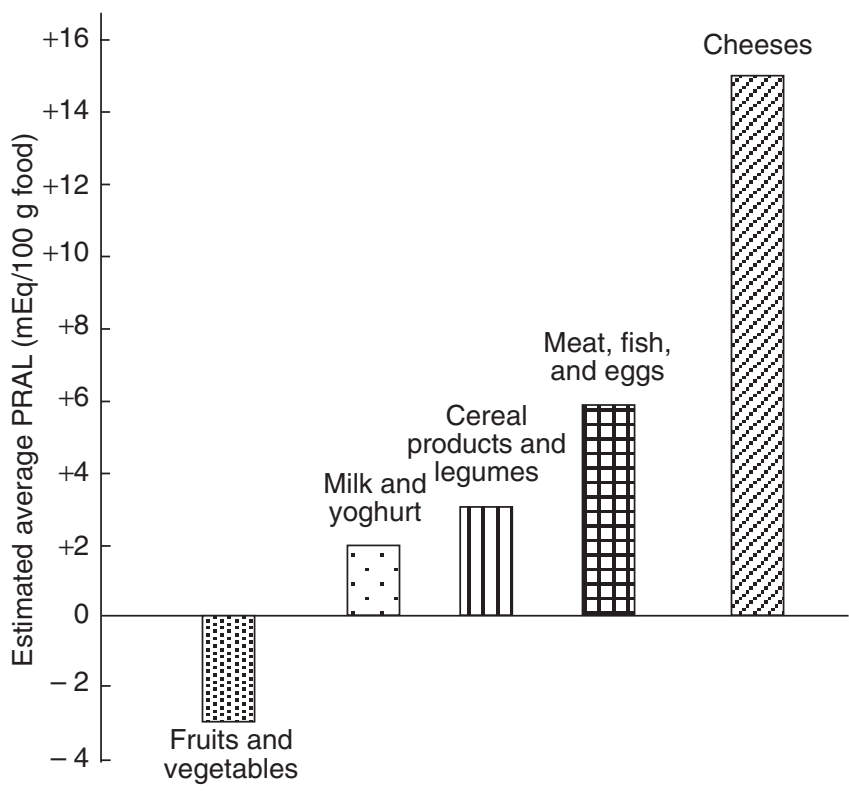

Fig 3. Average potential acid renal load (PRAL) values for the major categories of foods. (Adapted from Remer \& Manz, 1995; Remer, 2000.) 
diets. However, although protein was associated with an increased risk of forearm fracture for women who consumed more than $95 \mathrm{~g} / \mathrm{d}$, Feskanich et al. (1996) did not find any association between adult protein intake and the incidence of hip fracture. Also, it has to be said that a low protein intake may also compromise bone quality, especially in the elderly (Bonjour et al. 1997). In fact, the influence of dietary protein on Ca retention is complex, possibly transitory (Roughead et al. 2003), and liable to be modified by other nutrients in the diet (Massey, 2003).

\section{Role of potassium and sodium}

The addition of exogenous buffers, as chemical salts or as fruits and vegetables, to a high-protein diet results in a reduction in net acid excretion and decreased calciuria (Barzel \& Massey, 1998). Metabolic balance studies have shown that restoring intakes of $\mathrm{K}^{+}$and $\mathrm{HCO}_{3}^{-}$to levels approaching those in the diet of our prehistoric forebears with either supplemental $\mathrm{KHCO}_{3}$ or with fruits and vegetables can alleviate hypertension, prevent kidney stones and protect against the occurrence of osteoporosis (Morris et al. 2000). Accordingly, low $\mathrm{K}$ intakes increase daily and fasting urinary $\mathrm{Ca}$ excretion rates (Lemann, 1999). This Casparing effect occurs through reduced bone resorption and increased formation (Sebastian et al. 1994), whether the K salt is citrate or bicarbonate. Indeed, commonly complex dietary proteins with a high $\mathrm{P}$ content (Spencer et al. 1988) or consumed together with $\mathrm{KHCO}_{3}$ supplementation (Sebastian et al. 1994) do not cause Ca loss in adults. In the study of Lutz (1984), subjects had a similar Ca balance when consuming either the higher-protein diet (102 g) plus bicarbonates or a moderate-protein diet $(44 \mathrm{~g})$.

The human body has a very low need for salt but we become addicted to the taste of salt as a consequence of its widespread and essential use as a food preservative. There is evidence that the range of usual dietary intakes is associated with urinary $\mathrm{Ca}$ loss, leading to adverse effects on bone metabolism because renal clearance of both minerals is linked in the proximal renal tube (Shortt \& Flynn, 1990). Even if Ca homeostasis is generally well regulated (increased $\mathrm{Ca}$ loss triggers a better $\mathrm{Ca}$ absorption from the gut), the duration of this adaptive process may not be sufficient. This is why only $3 \%$ of the variance in urinary $\mathrm{Ca}$ excretion could be explained by $\mathrm{Ca}$ intake (Matkovic et al. 1995). It has been estimated that a $100 \mathrm{mmol}$ increment in daily $\mathrm{Na}$ intake is associated with an average Ca loss in urine of approximately $1 \mathrm{mmol}$ in free-living normocalciuric healthy populations (Nordin et al. 1993). Thus, if uncorrected, excess Na would lead to an annual skeletal loss of about $1 \%$ (Weaver et al. 1999). However, the limited studies which have investigated such an association with bone mineral density in human subjects have produced conflicting results. Actually, Ginty et al. (1998) have shown that adaptation of absorption may compensate for increased urinary Ca loss, at least in healthy young women. Results from Greendale et al. (1994) did not support a detrimental effect (prospective study from the Rancho-Bernado cohort). Nevertheless, other studies in adults implicated $\mathrm{Na}$ as a risk factor for urinary Ca loss (Massey \& Whiting, 1996), bone loss (Devine et al. 1995) and high bone resorption (Jones et al. 1997).

\section{Anti-acidosis mechanisms operating in kidneys}

Under steady-state conditions, the urinary output of electrolytes matches gastrointestinal electrolyte absorption. The kidney sustains normal acid-base homeostasis by reabsorbing an appropriate amount of the filtered bicarbonate and excreting a quantity of acid in urine that corresponds with the endogenously generated acid load.

Phosphate is the major buffer system in urine and its excretion is increased during acidosis, probably as a result of a decrease of the preferentially transported form $\left(\mathrm{HPO}_{4}{ }^{2-}\right)$ together with a direct effect of $\mathrm{pH}$ on the apical phosphate carrier in the proximal tubule. Citrate transport is frequently analysed owing to its sensitivity to systemic $\mathrm{pH}$; changes in citrate excretion are altered by changes in the transported chemical form, namely citrate ${ }^{2-}$, and in kidney metabolism (Brennan et al. 1988). It is now well established that acidosis promotes hypocitraturia and the tubular reabsorption of citrate. The renal excretion of citrate is normally dependent on the net absorption of alkali from the digestive tract (Sakhaee et al. 1993), but this relationship is less tight in subjects suffering distal renal tubular acidosis. In general, lithiasic subjects who have no renal tubular acidosis frequently exhibit hypocitraturia, which is chiefly of digestive origin and probably consecutive to an insufficient intake of alkalinising agents (fruits and vegetables). In this view, Hess et al. (1994) proposed that 'low vegetable-fibre intake and low urine volume' could be added to the list of risk factors for low urine citrate.

The actual mechanisms of the control of citraturia are now well known. In rats, in parallel with hypocitraturia, chronic acidosis increases the cortical activity of ATP citrate lyase (ACL). Abundance of the ACL protein in the renal cortex is dramatically enhanced within a few days, but there is little change in ACL mRNA (Melnick et al. 1998). Hypokaliemia also promotes hypocitraturia and a rise in ACL activity. Aconitase activity in the renal cortex mitochondria is affected by changes in the acid-base equilibrium (Melnick et al. 1998). In the rat, chronic metabolic acidosis and a $\mathrm{K}$ deficit result in a rise of aconitase activity, concomitant with a greater abundance of aconitase protein. Conversely, the administration of alkalinising agents in the diet may slightly depress aconitase activity. Activity of the $\mathrm{Na}^{+}$-citrate co-transporter in the apical membrane is enhanced by metabolic acidosis, but is not altered by the addition of alkalinising agents in the diets. Aruga et al. (2000) have shown that the abundance of $\mathrm{Na}^{+}$-dicarboxylate- 1 co-transporter protein is enhanced by chronic acidosis, in parallel with the corresponding mRNA. Likewise, it has been observed that several members of the $\mathrm{Na}-\mathrm{HCO}_{3}^{-}$ co-transporter family are up regulated in rats with chronic metabolic acidosis (Kwon et al. 2002).

\section{Physiopathological aspects}

\section{Acid-base status and calcium metabolism}

Because the urinary excretion of acid is insufficient, other homeostatic systems such as bone are required to buffer the excess dietary acid load (Barzel, 1995; Bushinsky, 2001; New, 2002). The skeleton serves as a substantial reservoir of labile base in the form of alkaline Ca salts, which can be 
mobilised to defend blood $\mathrm{pH}$. Indeed, $80 \%$ of total body carbonate is in the hydration shell, the water surrounding bone, as are $80 \%$ of citrate and $35 \%$ of $\mathrm{Na}$ (Green \& Kleeman, 1991). Osteoclasts and osteoblasts respond independently to small changes in $\mathrm{pH}$, a slight drop in $\mathrm{pH}$ causing a burst in bone resorption (Kriegger et al. 1992; Arnett \& Sakhaee, 1996). Further metabolic acidosis even blunts the capacity of growth hormone to stimulate the systemic production of insulin-like growth factor 1, which along with growth hormone is a major determinant of bone mass (Green \& Maor, 2000) (Table 2). Bone also plays a major role in the storage of phosphate, the phosphate buffer system being very important to relieve fixed acid loads and to enable the maintenance of $\mathrm{pH}$ within restricted limits (Pautard, 1961).

Thus, a negative $\mathrm{Ca}$ balance implies the depletion of bone mineral. Over 25 years ago, Wachman \& Bernstein (1968) suggested that lifetime buffering of the low-level acid loading and metabolic acidosis that occur in individuals eating ordinary diets was sufficient to impose a chronic demand for base of skeletal origin (Lennon et al. 1966). If bone is mobilised to buffer only $1 \mathrm{mEq}$ acid/d, $15 \%$ of the total body $\mathrm{Ca}$ in an average individual is lost in a decade (Barzel \& Massey, 1998). This is why Nordin et al. (1987) suggested that age-related bone loss may be more attributable to excessive $\mathrm{Ca}$ loss than to inadequate $\mathrm{Ca}$ intake.

Chronic metabolic acidosis due to excessive intakes of sulfate and chloride anions increases with age at constant endogenous acid production, apparently due to the normal age-related decline of renal function (Frassetto et al. 1996). Thus, though mild, it leads to high losses of $\mathrm{Ca}$ in the urine and has been implicated in the pathogenesis of the physiological disturbances and degenerative diseases characteristic of ageing such as osteoporosis (through enhanced bone resorption) (Lemann et al. 1986; New, 2002). Indeed, experimentally induced chronic metabolic acidosis by acid loading induced the loss of bone mass (Barzel \& Jowsey, 1969). In vitro, short-term metabolic acidosis (3 h culture) elicits a $\mathrm{Ca}$ efflux, secondary to physiochemical bone mineral dissolution, while over $24 \mathrm{~h}$ it results from cellmediated bone resorption (Bushinsky, 1995) because acidosis causes a greater release of $\mathrm{K}$ than $\mathrm{Ca}$ and osteoclastic function is necessary to support this phenomenon (Bushinsky, 2001).

\section{Acid-base status and protein metabolism}

Metabolic acidosis induces $\mathrm{N}$ wasting and depresses protein metabolism in human subjects. This may be particularly critical in aged individuals, more prone to renal dysfunction, and could promote muscle dystrophy and an aggravation of the consequences of $\mathrm{Ca}$ losses, through alterations of the protein matrix of bones. The committed mechanisms involved in the connection between acid-base equilibrium and protein metabolism are certainly complex and still incompletely understood. Nevertheless, there is little doubt that glutamine is a key factor, as a precursor of ammonium and bicarbonate in kidneys (Welbourne \& Joshi, 1990) as well as an effector of cellular metabolism, as shown in the liver through glutamine-induced $\mathrm{p} 38^{\mathrm{MAPK}}$ activation mediating the inhibition of autophagic proteolysis at the level of autophagosome formation (Häussinger et al.2001). In the same way, even small corrections of serum bicarbonate in acidotic subjects apparently promote the down regulation of branched-chain amino acid degradation (Rodriguez-Bayona \& Peragon, 1998) and muscle proteolysis via the ubiquitin-proteasome system which plays a central role in the control of the proteolytic pathway (Combaret et al. 2001; Pickering et al. 2002).

The acidosis-induced alterations in protein metabolism involve various endocrine systems, including a decrease in insulin-like growth factor 1 levels (due to a loss of peripheral growth hormone sensitivity), moderate hyperthyroidism and hyperglucorticoidism (Greiber \& Mitch, 1992; Wiederkehr \& Krapf, 2001). In addition, various metabolic disturbances liable to be accompanied by acidosis (diabetes, sepsis) result in a decrease in insulin action on protein synthesis or degradation but, in contrast, the

Table 2. Chronic effects of metabolic acidosis

\begin{tabular}{lll}
\hline Function & Process & Organ or tissue \\
\hline General cellular effects & K (and Mg) efflux from the cells & Muscles \\
Protein metabolism & Tissue protein degradation $\uparrow$ & Muscles \\
& BCAA oxidation $\uparrow$ & \\
& Albumin synthesis $\downarrow$ & Liver \\
Ca homeostasis & Ca mobilisation $\uparrow$ & Bone \\
& Active vitamin D synthesis $\downarrow$ & Several organs \\
Glucose metabolism & Gluconeogenesis and lactate utilisation $\downarrow$ & Liver \\
& Gluconeogenesis and Gln utilisation $\uparrow$ & Kidney \\
Excretory function & Ca and P excretion $\uparrow$ & Kidney \\
& Citrate excretion $\downarrow$ & \\
Oxidative status & Lithiasis risk $\uparrow$ & \\
& Free Fe and Cu $\uparrow$ & Blood plasma \\
Endocrine functions & Others ? & \\
& GH secretion $\downarrow$ & Hypophyse \\
& GH receptor expression $\downarrow$ & Liver \\
& IGF-1 expression $\downarrow$ & Chondrocytes \\
\hline
\end{tabular}

$\uparrow$, Increase; BCAA, branched-chain amino acids; $\downarrow$, decrease; GIn, glutamine; GH, growth hormone; IGF, insulin-like growth factor. 
antiproteolytic action of insulin could be improved during hyperthyroidism (Grizard et al. 1999).

\section{Acidosis and peroxidation of biological structures}

An acidification of extracellular $\mathrm{pH}$ may enhance LDL oxidation, by shortening the 'lag phase' and accelerating hydroperoxides and thiobarbituric acid-reactive substances formation. These alterations themselves promote their uptake by macrophages (Morgan \& Leake, 1995). One of the mechanisms whereby variations of acid-base equilibrium might affect the processes of peroxidation is by changes in bioavailability of cations such as $\mathrm{Fe}$ or $\mathrm{Cu}$ (Leake, 1997; Salovaara et al. 2002). Fe is carried by transferrin on specific clusters of amino acids and an acidification of plasma $\mathrm{pH}$ can protonate these amino acids and release $\mathrm{Fe}$ from its binding sites. However, this last effect is significant only for definitely acidic and unphysiological $\mathrm{pH}$, sometimes lower than 6. Effects on $\mathrm{Cu}$ availability $\mathrm{Cu}$ is considered as more potent than Fe to initiate LDL oxidation) through a release of $\mathrm{Cu}$ from caeruloplasmin are obtained with less drastic acidification ( $\mathrm{pH} 7)$. It must be noted that these studies were generally carried out on ex vivo systems, which explains why severely disturbing or even potentially lethal $\mathrm{pH}$ values could be studied. Nevertheless, some authors consider that, in the presence of metabolic acidosis (ketoacidosis, renal deficiency) even effectively compensated with modest change in blood $\mathrm{pH}$, the buffering capacity of interstitial fluid may be severely depressed, thus allowing the emergence of local sites of severe acidosis (for example, near atheromatous lesions where LDL oxidation chiefly takes place). Deleterious effects of a prolonged period of systemic acidosis could also affect the internal structures of tissues and cells, through various mechanisms such as intracellular $\mathrm{K}$ and $\mathrm{Mg}$ losses and $\mathrm{Ca}$ movements between its various subcellular pools.

\section{Conclusions on the role of fruit and vegetables}

Clearly, dietary factors affecting the amount of $\mathrm{Ca}$ lost in the urine have a major influence on $\mathrm{Ca}$ balance and may even be more important than those that modulate the intestinal availability of $\mathrm{Ca}$. This is why the inevitable loss of $\mathrm{Ca}$ in the urine is greater for Western-type diets rich in factors such as animal proteins, sulfate, $\mathrm{Na}$ or coffee (Heaney \& Recker, 1982; Guéguen \& Pointillart, 2000). The critical determinant of hip-fracture risk in relation to the acid-base effects of diet is the net load of acid in the diet. Thus, it is worthwhile to consider decreasing the rate of bone attrition by the use of a diet favouring alkaline ash, which leads to the promotion of fruit and vegetable intake (Remer \& Manz, 1995; Frassetto et al. 1996). New et al. $(1997,2000)$ report that fruit consumption predicted greater bone density at all four bone sites measured in postmenopausal women and, when $\mathrm{K}$ was considered, Ca intake was no longer significantly related to bone mass. Tucker et al. (1999) have confirmed, in a cross-sectional and longitudinal study, that alkaline-producing dietary components such as $\mathrm{K}$ contribute to the maintenance of bone density. An increase in fruit and vegetable intake from 3.6 to 9.5 daily servings decreased urinary $\mathrm{Ca}$ from 157 (SD 7) to 110 (SD 7) $\mathrm{mg} / \mathrm{d} v$. a drop of $14 \pm 6$ in controls (Appel et al. 1997). In conclusion, greater attention needs to be paid to the causes of $\mathrm{Ca}$ loss, which should lower the $\mathrm{Ca}$ requirement. Indeed, urinary losses remain an important and inadequately appreciated aspect of $\mathrm{Ca}$ nutrition. A diet may be inadequate in $\mathrm{Ca}$ not simply because it is intrinsically $\mathrm{Ca}$ poor but also because it is insufficient to offset excretory losses.

From a practical point of view, a supply of $\mathrm{K}$ in the range of $2 \cdot 5-3 \cdot 5 \mathrm{~g} / \mathrm{d}$ as fruits and vegetables supposes a substantial intake of these plant foods, namely $0.6-0.8 \mathrm{~kg} / \mathrm{d}$ (assuming a mean concentration of $3 \mathrm{~g} / \mathrm{kg}$ fw). Such a supply would be possible in the framework of 'ten per d' recommendations for fruit and vegetable consumption, with servings of an average 80-100 g weight. These recommendations could seem high and not realistic, but it must be kept in mind that they are already fulfilled by a noticeable percentage of the population, including not only vegetarians but also a fraction of omnivorous subjects.

\section{References}

Abelow BJ, Holford TR \& Insogna KL (1992) Cross cultural association between dietary animal protein and hip fracture: a hypothesis. Calcified Tissue International 50, 14-18.

Albihn PB \& Savage GP (2001) The bioavailability of oxalate from Oca (Oxalis tuberosa). Journal of Urology 166, 420-422.

Appel LJ, Moore TJ, Obarzanek E, Vollmer WM, Svetkey LP, Sacks FM, Bray GA, Vogt TM, Cutler JA, Windhauser MM, Lin PH \& Karanja N (1997) A clinical trial of the effects of dietary patterns on blood pressure. New England Journal of Medicine 336, 1117-1124.

Aprikian O, Duclos V, Guyot S, Besson C, Manach C, Bernalier A, Morand C, Rémésy C \& Demigné C (2003) Apple pectin and a polyphenol-rich apple concentrate are more effective together than separately on cecal fermentations and plasma lipids in rats. Journal of Nutrition 133, 1860-1865.

Arnett RJ \& Sakhaee K (1996) Modulation of the resorptive activity of rat osteoclasts by small changes in extracellular $\mathrm{pH}$ near the physiological range. Bone 18, 277-279.

Aruga S, Wehrli S, Kaissling B, Moe OW, Preisig PA, Pajor AM \& Alpern RJ (2000) Chronic metabolic acidosis increases Na DC-1 mRNA and protein abundance in rat kidney. Kidney International 58, 206-215.

Barzel US (1995) The skeleton as an ion exchange system: implications for the role of acid-base imbalance in the genesis of osteoporosis. Journal of Bone and Mineral Research 10, 1431-1436.

Barzel US \& Jowsey J (1969) The effects of chronic acid and alkali administration on bone turnover in adult rats. Clinical Science 36, 517-524.

Barzel US \& Massey LK (1998) Excess dietary protein can adversely affect bone. Journal of Nutrition 128, 1051-1053.

Bonjour JP, Schurch MA \& Rizzoli R (1997) Proteins and bone health. Pathological Biology 45, 57-59.

Brennan S, Hering-Smith K \& Hamm LL (1988) Effects of pH on citrate reabsorption in the proximal convoluted tubule. American Journal of Physiology 255, F301-F306.

Bushinsky DA (1995) Stimulated osteoclastic and suppressed osteoblastic activity in metabolic but not respiratory acidosis. American Journal of Physiology 268, C80-C88.

Bushinsky DA (2001) Acid-base imbalance and the skeleton. European Journal of Nutrition 40, 238-244.

Chadwick VS, Vince A, Killingley M \& Wrong OM (1978) The 
metabolism of tartrate in man and the rat. Clinical Science and Molecular Biology 54, 273-281.

Combaret L, Taillandier D \& Attaix D (2001) Nutritional and hormonal control of protein breakdown. American Journal of Kidney Diseases 37, S108-S111.

Cummings JH \& Macfarlane GT (1997) Role of intestinal bacteria in nutrient metabolism. Journal of Parenteral and Enteral Nutrition 21, 357-365.

De Groot AP, Lina BAR, Hagenaars AJM, Hollanders VMH, Andringa M \& Feron VJ (1995) Effects of a dietary load of acid or base on changes induced by lactose in rats. Food and Chemical Toxicology 33, 1-14.

Demigné C, Rémésy C \& Morand C (1999) Short chain fatty acids. In Colonic Microbiota, Nutrition and Health, pp. 55-70 [GR Gibson and MB Roberfroid, editors]. Dordrecht, The Netherlands: Kluwer.

Devine A, Criddle RA, Dick IM, Kerr DA \& Prince RL (1995) A longitudinal study of the effect of sodium and calcium intakes on regional bone density in postmenopausal women. American Journal of Clinical Nutrition 62, 740-745.

Feskanich D, Willett WC, Stampfer MJ \& Colditz GA (1996) Protein consumption and bone fractures in women. American Journal of Epidemiology 143, 472-479.

Frassetto LA, Morris RC \& Sebastian A (1996) Effect of age on blood acid-base composition in adult humans: role of agerelated renal function decline. American Journal of Physiology 271, F1114-F1122.

Frassetto LA, Morris RC Jr, Sellmeyer DE, Todd K \& Sebastian A (2001) Diet, evolution and aging: the pathophysiologic effects of the post-agricultural inversion of the potassium-to-sodium and base-to-chloride ratios in the human diet. European Journal of Nutrition 40, 200-213.

Frassetto LA, Todd KM, Morris RC \& Sebastian A (2000) Worldwide incidence of hip fracture in elderly women: relation to consumption of animal and vegetable foods. Journal of Gerontology 55A, M585-M592.

Ginty F, Flynn A \& Cashman K (1998) The effect of sodium intake on biochemical markers of bone metabolism in young women. British Journal of Nutrition 79, 343-350.

Green J \& Kleeman R (1991) Role of bone in regulation of systemic acid-base balance. Kidney International 39, 9-26.

Green J \& Maor G (2000) Effect of metabolic acidosis on the growth hormone/IGF-I endocrine axis in skeletal growth centers. Kidney International 57, 2258-2267.

Greendale GA, Barrett-Connor E, Edelstein S, Ingles S \& Haile R (1994) Dietary sodium and bone mineral density: results of a 16-year follow-up study. Journal of the American Geriatrics Society 42, 1050-1052.

Greiber S \& Mitch WE (1992) Mechanisms for protein catabolism in uremia: metabolic acidosis and activation of proteolytic pathways. Mineral and Electrolyte Metabolism 18, 233-236.

Grizard J, Dardevet J, Balage M, Larbaud D, Sinaud S, Savary I, Grzelkowska K, Rochon C, Tauveron I \& Obled C (1999) Insulin action on skeletal muscle protein metabolism during catabolic states. Reproduction, Nutrition, Development 39, 61-74.

Guéguen L \& Pointillart A (2000) The bioavailability of dietary calcium. Journal of the American College of Nutrition 19, 119S-136S.

Hatch M \& Freel RW (1995) Alterations in intestinal transport of oxalate in disease states. Scanning Microscopy 9, 1121-1126.

Häussinger D (1997) Liver regulation of acid base balance. Mineral and Electrolyte Metabolism 23, 249-254.

Häussinger D, Graf D \& Weiergräber OH (2001) Glutamine and cell signaling in liver. Journal of Nutrition 131, Suppl., 2509S-2514S

Häussinger D, Stoll B, Stehle T \& Gerok W (1989) Hepatocyte heterogeneity in glutamate metabolism and bidirectional trans- port in perfused rat liver. European Journal of Biochemistry 185, 189-195.

Hautmann RE (1993) The stomach: a new powerful oxalate absorption site in man. Journal of Urology 149, 1401-1404.

Heaney RP (2001) Protein intake and bone health: the influence of belief systems on the conduct of nutritional science. American Journal of Clinical Nutrition 73, 5-6.

Heaney RP \& Recker RR (1982) Effects of nitrogen, phosphorus, and caffeine on calcium balance in women. Journal of Laboratory and Clinical Medicine 99, 46-55.

Hess B, Michel R, Takkinen R, Ackermann D \& Jaeger P (1994) Risk factors for low urinary citrate in calcium nephrolithiasis: low vegetable fibre intake and low urine volume to be added to the list. Nephrology Dialysis Transplantation 9, 642-649.

Heymsfield SB, Allison DB, Vasselli JR, Pietrobelli A, Greenfield D \& Nunez C (1998) Garcinia cambodgia (hydroxycitric acid) as a potential antiobesity agent: a randomized controlled trial. Journal of the American Medical Association 280, 1596-1600.

Jones G, Beard T, Parameswaran V, Greenaway T \& Von Witt R (1997) A population-based study of the relationship between salt intake, bone resorption and bone mass. European Journal of Clinical Nutrition 51, 561-565.

Kriegger NS, Sessler NE \& Bushinsky DA (1992) Acidosis inhibits osteoblastic and stimulates osteoclastic activity in vitro. American Journal of Physiology 262, F442-F448.

Kunzelmann K \& Mall M (2002) Electrolyte transport in the mammalian colon: mechanisms and implications for disease. Physiological Reviews 82, 245-289.

Kwon T-H, Fulton C, Wang W, Kurtz I, Frokiear J, Aalkjaer C \& Nielsen S (2002) Chronic metabolic acidosis upregulates rat kidney $\mathrm{Na}_{-} \mathrm{HCO}_{3}{ }^{-}$cotransporters $\mathrm{NBCn} 1$ and $\mathrm{NBC} 3$ but not NBC1. American Journal of Physiology 282, F341-F351.

Leake DS (1997) Does an acidic pH explain why low density lipoprotein is oxidised in atherosclerotic lesions? Atherosclerosis 129, 149-157.

Lemann J (1999) Relationship between urinary calcium and net acid excretion as determined by dietary protein and potassium: a review. Nephron 81, 18-25.

Lemann J, Gray RW, Maierhofer WJ \& Cheung HS (1986) The importance of renal net acid excretion as a determinant of fasting urinary calcium excretion. Kidney International 29, 743-746.

Lennon EJ, Lemann J \& Litzow JR (1966) The effect of diet and stool composition on the net external acid balance of normal subjects. Journal of Clinical Investigation 45, 1601-1607.

Lutz J (1984) Calcium balance and acid-base status of women as affected by increased protein intake and by sodium bicarbonate ingestion. American Journal of Clinical Nutrition 39, 281-288.

Massey LK (2003) Dietary animal and plant protein and human bone health: a whole food approach. Journal of Nutrition 133 862S-865S.

Massey LK \& Whiting SJ (1996) Dietary salt, urinary calcium and bone loss. Journal of Bone and Mineral Research 11, 731-736.

Matkovic V, Ilich JZ \& Andon MB (1995) Urinary calcium, sodium, and bone mass of young females. American Journal of Clinical Nutrition 62, 417-425.

Melnick JZ, Preisig PA, Moe OW, Srere P \& Alpern RJ (1998) Renal cortical aconitase is regulated in hypo- and hypercitraturia. Kidney International 54, 160-165.

Morgan J \& Leake DS (1995) Oxidation of low density lipoprotein by iron or copper at acidic pH. Journal of Lipid Research 36, 2504-2512.

Morris RC, Schmidlin O, Tanaka M, Forman A, Frassetto L \& Sebastian A (2000) Differing effects of supplementary $\mathrm{KCl}$ and $\mathrm{KHCO}_{3}$ : pathophysiological and clinical implication. Seminars in Nephrology 19, 487-493.

Mortensen PB \& Clausen MR (1996) Short-chain fatty acids in the human colon: relation to gastrointestinal health and disease. Scandinavian Journal of Gastroenterology 216, Suppl., 132-148. 
Moseley RH, Jarose S \& Permoad P (1992) Hepatic Na(+)-dicarboxylate cotransport: identification, characterization, and acinar localization. American Journal of Physiology 263, G871-G879.

New SA (2002) The role of the skeleton in acid-base homeostasis. Proceedings of the Nutrition Society 61, 151-164.

New SA, Bolton-Smith C, Grubb DA \& Reid DM (1997) Nutritional influences on bone mineral density: a cross-sectional study in premenopausal women. American Journal of Clinical Nutrition 65, 1831-1839.

New SA, Robins SP, Campbell MK, Martin JC, Garton MJ, BoltonSmith C, Grubb DA, Lee SJ \& Reid DM (2000) Dietary influences on bone mass and bone metabolism: further evidence of a positive link between fruit and vegetable consumption and bone health? American Journal of Clinical Nutrition 71, 142-151.

Nordin BEC, Need AG, Morris HA \& Horowitz M (1993) The nature and significance of the relationship between urinary sodium and urinary calcium in women. Journal of Nutrition 123, 1615-1622.

Nordin BEC, Polley KJ, Need AG, Morris HA \& Marshall D (1987) The problem of calcium requirement. American Journal of Clinical Nutrition 45, 1295-1304.

Oh MS (2000) New perspectives on acid-base balance. Seminars in Dialysis 13, 212-219.

Pajor AM (1999) Citrate transport by the kidney and intestine. Seminars in Nephrology 19, 195-200.

Pautard FGE (1961) Calcium, phosphorus and the origins of back bones. New Science 260, 364-366.

Pickering WP, Price SR, Bircher G, Marivonic AC, Mitch WE \& Walls J (2002) Nutrition in CAPD: serum bicarbonate and the ubiquitin-proteasome system in muscle. Kidney International 61, 1286-1292.

Remer T (2000) Influence of diet on acid-base balance. Seminars in Dialysis 13, 221-226.

Remer T \& Manz F (1995) Potential renal acid load of foods and its influence on urine pH. Journal of the American Dietetic Association 95, 791-797.

Rodriguez-Bayona B \& Peragon J (1998) Stimulation of rat-liver branched-chain alpha-keto acid dehydrogenase activity by chronic metabolic acidosis. The International Journal of Biochemistry and Cell Biology 30, 529-534.

Roughead ZK, Johnson LK, Lykken GI \& Hunt JR (2003) Controlled high meat diets do not affect calcium retention or indices of bone status in healthy postmenopausal women. Journal of Nutrition 133, 1020-1026.

Sakhaee K, Williams RH, Oh MS, Paladino P, Adams-Huet B, Whitson P \& Pak CY (1993) Alkali absorption and citrate excretion in calcium nephrolithiasis. Journal of Bone and Mineral Research 8, 789-794.

Salovaara S, Sandberg AS \& Andlid T (2002) Organic acids influence iron uptake in the human epithelial cell line Caco-2. Journal of Agricultural and Food Chemistry 50, 6233-6238.
Sebastian A, Harris ST, Ottaway JH, Todd KM \& Morris RC (1994) Improved mineral balance and skeletal metabolism in postmenopausal women treated with potassium bicarbonate. New England Journal of Medicine 330, 1776-1781.

Sellin JH (1999) SCFAs: the enigma of weak electrolyte transport in the colon. News in Physiology 14, 58-64.

Sellmeyer DE, Stone KL, Sebastian A \& Cummings SR (2001) A high ratio of dietary animal to vegetable protein increases the rate of bone loss and the risk of fracture in postmenopausal women. American Journal of Clinical Nutrition 73, 118-122.

Shortt C \& Flynn A (1990) Sodium-calcium inter-relationships with specific reference to osteoporosis. Nutrition Research Reviews 3, 101-115.

Spencer H, Kramer L \& Osis D (1988) Do protein and phosphorus cause calcium loss? Journal of Nutrition 118, 657-660.

Stoll B, McNelly S, Buscher HP \& Haussinger D (1991) Functional hepatocyte heterogeneity in glutamate, aspartate and alpha-ketoglutarate uptake: a histoautoradiography study. Hepatology 13, 247-253.

Tucker KL, Hannan MT, Chen H, Cupples LA, Wilson PW \& Kiel DP (1999) Potassium, magnesium, and fruit and vegetable intakes are associated with greater bone mineral density in elderly men and women. American Journal of Clinical Nutrition 69, 727-736.

Wachman A \& Bernstein DS (1968) Diet and osteoporosis. Lancet i, 958-959.

Walaszek Z, Szemraj J, Narog M, Adams AK, Kilgore J, Sherman U \& Hanausek M (1997) Metabolism, uptake, and excretion of a D-glucaric acid salt and its potential use in cancer prevention. Cancer Detection and Prevention 21, 178-190.

Weaver CM, Proulx WR \& Heaney R (1999) Choices for achieving adequate dietary calcium with a vegetarian diet. American Journal of Clinical Nutrition 70, Suppl., 543S-548S.

Welbourne TC \& Joshi S (1990) Interorgan glutamine metabolism during acidosis. Journal of Parenteral and Enteral Nutrition 14, 77S-85S.

Wiederkehr M \& Krapf R (2001) Metabolic and endocrine effects of metabolic acidosis in humans. Swiss Medical Weekly 131, $127-132$

Wolffram S, Unternahrer R, Grenacher B \& Scharrer E (1994) Transport of citrate across the brush border and basolateral membrane of rat small intestine. Comparative Biochemistry and Physiology 109, 39-52.

Yoshimi N, Walaszek Z, Mori H, Hanausek M, Szemraj J \& Slaga TJ (2000) Inhibition of azoxymethane-induced rat colon carcinogenesis by potassium hydrogen D-glucarate. International Journal of Oncology 16, 43-48.

Zimmerli B, O’Neill B \& Meier PJ (1992) Identification of sodium-dependent and sodium-independent dicarboxylate transport systems in rat liver basolateral membrane vesicles. Pflugers Archiv 421, 329-335. 